\title{
Effects of Clove Oil and Lidocaine-HCl Anesthesia on Water Parameter during Simulated Transportation in the Marine Medaka, Oryzias dancena
}

\author{
${ }^{\dagger}$ In-Seok Park ${ }^{1}{ }^{*}$ Hyun Woo Gil ${ }^{1}$, Tae Ho Lee ${ }^{1}$, Yoon Kwon Nam ${ }^{2}$, \\ Sang Gu Lim ${ }^{3}$ and Dong Soo Kim ${ }^{2}$ \\ ${ }^{1}$ Division of Marine Bioscience, College of Ocean Science and Technology, Korea Maritime \\ and Ocean University, Busan 606-791, Korea \\ ${ }^{2}$ Institute of Marine Living Modified Organisms (iMLMO), Pukyung National University, Busan 608-737, Korea \\ ${ }^{3}$ Future Aquaculture Research Center, National Fisheries Research \& Development Institute, Jeju 690-192, Korea
}

\begin{abstract}
Optimum concentrations of anesthetic clove oil and anesthetic lidocaine-HCl were determined for a species of adult marine medaka, Oryzias dancena, over a range of salinity conditions, and investigated in a transport simulation experiment by analyzing various water and physiological parameters. Research indicated that the higher the concentration of anesthetic at each salinity, the shorter the anesthesia time at each salinity. At each concentration, fish were anesthetized slower at water salinities over $10 \mathrm{ppt}(P<0.05)$. Anesthesia time at $10 \mathrm{ppt}$ was faster than any other salinity. In $10 \mathrm{ppt}$ salinity, the dissolved oxygen (DO) concentrations and respiratory frequencies of the clove-oil-administered groups decreased until 48 hours $(P<0.05)$, whereas the $\mathrm{NH}_{4}{ }^{+}$and $\mathrm{CO}_{2}$ concentrations increased until 48 hours $(P<0.05)$. In same period, the $\mathrm{DO}, \mathrm{NH}_{4}{ }^{+}$, and $\mathrm{CO}_{2}$ concentrations and respiratory frequencies all decreased as the clove oil concentration increased $(P<0.05)$. The trends in the $\mathrm{DO}, \mathrm{NH}_{4}{ }^{+}$, and $\mathrm{CO}_{2}$ concentrations and respiratory frequencies in the lidocaine-HCl-administered groups were similar to those in the clove-oil-administered groups. In conclusion, clove oil and lidocaine- $\mathrm{HCl}$ are effective anesthetics, improving the transportation of the marine medaka. The results from this study will contribute to safe laboratory handling of the marine medaka, which are commonly required by many research studies and experiments.
\end{abstract}

Key words : Anesthesia, Clove oil, Lidocaine-HCl, Marine medaka, Oryzias dancena, Salinity, Water parameters

\section{INTRODUCTION}

The marine medaka, Oryzias dancena (Beloniformes; Teleostei), is a euryhaline teleost that mainly inhabits the brackish or freshwater of river mouths and estuaries around Bengal Bay and the Malay Peninsula (Roberts, 1998). It also has a short interval between generations, with spawning possibilities just 60 days after hatching (Kim et al., 2009a; Goo et al., 2015). Most of its physiological attributes are similar across a wide spectrum of salinities, ranging from complete freshwater to normal seawater (Inoue \& Takei, 2003; Kang et al., 2008; Goo et al., 2015). The marine medaka isn't indigenous to Korea. However, this species is accredited by the Ministry of Land, Transport and Maritime Affairs, Korea (Ordinance of Agriculture, Food and Fisheries, No. 1) and is imported legally

\footnotetext{
Manuscript received December 28, 2016, Received in revised form December 31, 2016, Accepted January 8, 2017

${ }^{\dagger}$ Corresponding Author : In-Seok Park, Division of Marine Bioscience, College of Ocean Science and Technology, Korea Maritime and Ocean University, Busan 606-791, Korea. Tel.: +82-51-410-4321, Fax: +82-51-404-4750, E-mail: ispark@kmou.ac.kr

${ }^{*}$ Co-corresponding author : Hyun Woo Gil, Division of Marine Bioscience, College of Ocean Science and Technology, Korea Maritime and Ocean University, Busan 606-791, Korea. Tel.: +82-51-410-4321, Fax: +82-51-404-4750, E-mail: ulyian1119@nate.com

This is an Open Access article distributed under the terms of the Creative Commons Attribution Non-Commercial License (http:// creativecommons.org/licenses/by-nc/3.0) which permits unrestricted non-commercial use, distribution, and reproduction in any medium, provided the original work is properly cited.
} 
from Indonesia (Kim et al., 2009a, 2009b). Recently, the Institute of Marine Living Modified Organisms ( $i$ MLMO) selected this species for a living modified organism evaluation project. In line with this purpose, detailed information on marine medaka biology has begun to be exploited, especially regarding early gonadogenesis, sex differentiation, early ontogenesis, and embryogenesis (Kim et al., 2009a, 2009b). In addition, Nam et al. (2010) researched tolerance capacity to salinity changes in this species. This species is highly capable of hyper-osmoregulation as well as hypoosmoregulation. Also, no marine medaka in the experimental group (0 to $40 \mathrm{ppt}$ ) died from stress of salinity changes (Nam et al., 2010).

An effective high-density transport method for fish is essential to minimize stress and reduce the chance of mass mortality (Ferreira et al., 1984) during long periods of transportation and handling, and to reduce expenses and avoid losses (Ferreira et al., 1984; Staurnes et al., 1994). The production of new equipment and transport procedures has had increasingly positive effects on the transportation of live fish. In addition, anesthetics are also effective method of transporting fish. Because, the use of anesthetics in aquaculture reduces fish energy, allowing for the efficient transportation of fish, ease of handling when measurements are taken, a reduction in the pain and trauma experienced by experimental fish, and reduced handling stress (Park et al., 2009; Gil et al., 2016). For example, the use of nonpoisonous salt has been shown to alleviate stress and promote higher survival rates (Tomasso et al., 1980; Carmichael et al., 1984; Carmichael \& Tomasso, 1988; Gil et al., 2016). The use of low-concentration calcium chloride is a cheap and effective method of handling and transporting live fish (Grizzle et al., 1985; Carmichael \& Tomasso, 1988).

In recent years, Park et al. (2014) reported that anesthetic effect by changing water temperature (cold shock and heat shock). Temperature shock anesthesia in fish is cha- racterized by an absence of motion, reduced power of exertion, and diminished nervous sensitivity. Temperature shock anesthesia is reversible and leaves no residue in the tissues. No danger is imposed to the user, other than the risk inherent in handling solid carbon dioxide if that material is used (Park et al., 2014). But temperature shock anesthesia has short anesthetic time for handling samples. Mass mortality of samples may cause by this method, because process of this method is to faint by temperature shock. Therefore, based on the fact that it is safe, inexpensive, non-toxic to the environment and stable, and does not require a withdrawal period compared to other synthetic-based anesthetics, the use of clove oil and lidocaine- $\mathrm{HCl}$ has become more popular in the aquaculture industry (Kang et al., 2005; Park et al., 2011). The effects of clove oil and lidocaine- $\mathrm{HCl}$ as anesthetics have been studied in a number of fish species (Woody et al., 2002; Park et al., 2004, 2009, 2011; Gil et al., 2016).

However, previous research on marine medaka has investigated the effects of anesthetic clove oil and lidocaine$\mathrm{HCl}$ on water temperature and anesthetic effects of changing water temperature and stress responses in the marine medaka (Park et al., 2011; Park et al., 2014). No previous research has investigated the anesthetic effects of clove oil and lidocaine- $\mathrm{HCl}$ on the marine medaka during transportation. We have determined the aim of this research should concern a euryhaline teleost, so the marine medaka was chosen. The aim of this study was to determine optimum concentrations of anesthetic clove oil and anesthetic lidocaine- $\mathrm{HCl}$ for the marine medaka in various salinity conditions, and analyzing various physiological and water parameters by a simulation experiment in optimum salinity condition.

\section{MATERIALS AND METHODS}

\section{Fish production and sampling}


On 12 January 2009, 30 specimens of adult marine medaka, Oryzias dancena were obtained from $i \mathrm{MLMO}$, Pukyung National University, Korea. The fish were reared and bred in the Fishery Genetics and Breeding Sciences Laboratory of the Korea Maritime University. Ten thousand specimens of adult marine medaka were bred from the original 30 specimens in 11 months. The marine medaka used in the study were selected at random from the entire population. Samples were measured using an electronic balance (Shimadzu, Japan) and vernier caliper (Mitutoyo, Japan). Average body length and body weight of the group were $30.8 \pm 3.52 \mathrm{~mm}(n=50)$ and $334.9 \pm 60.04 \mathrm{mg}(n$ $=50)$, respectively.

\section{Condition of anesthesia}

The anesthetic experiment began on 29 December 2015 and ended on 20 February 2016. Fifty specimens from each of the groups were randomly selected for respective experiment to investigate the anesthetic effects of clove oil (Sigma, USA) and lidocaine-HCl (Hongsung Chemical, Korea). Five water salinities, 0, 10, 20, 30, and 40 ppt, were set for the study and anesthetic water salinity was identical with recovery water salinity. Water salinity of each group was regulated to be same as the anesthetic water salinity during the experiment. Until experiment termination, the water temperature was maintained at $26^{\circ} \mathrm{C}$. All the fish were deprived of food for 24 hours before the study. The study methods for the anesthetic effect of clove oil and lidocaine were taken from the methods of Park et al. (2011). Furthermore, all experiments were completed in duplicate.

\section{Criteria of anesthetic effect}

The decision-based anesthetic effect table shows the stages of anesthesia and recovery that were used as endpoints (only opercular movement: A6; normal swimming, responsiveness to visual stimuli: R6) in the present study
(Summerfelt \& Smith 1990; Woolsey et al., 2004; Park et al., 2011). During this experiment, anesthetizing marine medaka involved several stages, from slowed swimming speed and side to side rolling (stage A2) to only opercular movement (stage A6). At stage A6, individuals were transferred to a recovery tank. Recovery time was established as the point at which erratic swimming began. Recovery time included redressing the balance (stage R5) and normal swimming, as well as responsiveness to visual stimuli (stage R6).

\section{Respiratory frequency}

After anesthetic experiment, a simple sealed container, comprising an acrylic resin box with a wall thickness of 8 $\mathrm{mm}$ and overall dimensions of $10 \mathrm{~cm}$ (width) $\times 50 \mathrm{~cm}$ (length) $\times 10 \mathrm{~cm}$ (height), was used as a respirometer chamber. The hose for the inflow water was equipped with a temperature controller and $10 \mu \mathrm{m}$ and $3 \mu \mathrm{m}$ cartridge filters to exclude any particles. A flow-through ultraviolet lamp was used to reduce the oxygen consumption by microbes. The temperature of the water flowing into the respirometer chamber was maintained at $26 \pm 0.3{ }^{\circ} \mathrm{C}$ with a heater. The water salinity was maintained optimum anesthetic salinity by brackish water, and optimum anesthetic salinity of each group were analyzed by anesthetic experiment. The respirometer chambers were prepared and labeled according to the measurement times and anesthetic concentrations.

\section{Criteria of water parameter effect}

For determine the appropriate experimental concentrations of clove oil and lidocaine- $\mathrm{HCl}$, we performed a pilot experiment for 48 hours. To prevent mortality in the experimental sample, the anesthetized marine medaka were maintained at several levels of anesthesia during the pilot study, ranging from normal swimming, opercular movement, and general movement (stage A1) to slow swimming 
and side-to-side rolling (stage A2) (Summerfelt \& Smith, 1990; Woolsey et al., 2004; Park et al., 2011). The anesthetic effects of clove oil were determined at five concentrations: $0.2,0.4,0.6,0.8$, and $1 \mathrm{ppm}$. The stock solution of clove oil was dissolved in 95\% methanol (Sigma, St. Louis, USA) at a ratio of $1: 10$. The effects of lidocaine- $\mathrm{HCl}$ were determined at five concentrations: 20, 40, 60, 80, and 100 ppm. To neutralize the anesthetic solution (lidocaine- $\mathrm{HCl}$ solution) and to amplify its effect (Park et al., 2011), Na-
$\mathrm{HCO}_{3}$ (Sigma, St. Louis, USA) at a total concentration of 1,000 ppm was added to the solution.

\section{Water parameter in anaesthetic experiment}

Measurements were made at 6 hours intervals after experiment was begun, for 48 hours. Before the dissolved oxygen (DO) was measured, the concentrations of ammonium $\left(\mathrm{NH}_{4}{ }^{+}\right)$and carbon dioxide $\left(\mathrm{CO}_{2}\right)$ were measured with a spectrophotometer (DR2800, HACH, Loveland,

Table 1. Effects of clove oil dose and starting water salinity on anesthesia among marine medaka, Oryzias dancena

\begin{tabular}{|c|c|c|c|c|c|}
\hline \multirow{2}{*}{$\begin{array}{c}\text { Dose } \\
\left(\mathrm{mgL}^{-1}\right)\end{array}$} & \multicolumn{5}{|c|}{ Exposure time $(\mathrm{sec})^{*}$} \\
\hline & $0 \mathrm{ppt}$ & $10 \mathrm{ppt}$ & $20 \mathrm{ppt}$ & $30 \mathrm{ppt}$ & $40 \mathrm{ppt}$ \\
\hline 50 & $160.0 \pm 9.43^{\mathrm{b}}$ & $126.6 \pm 11.02^{\mathrm{a}}$ & $206.0 \pm 19.83^{c}$ & $218.6 \pm 40.25^{\mathrm{d}}$ & $226.4 \pm 39.10^{\mathrm{e}}$ \\
\hline 75 & $138.4 \pm 8.28^{\mathrm{b}}$ & $83.0 \pm 18.38^{\mathrm{a}}$ & $154.7 \pm 16.46^{\mathrm{c}}$ & $159.9 \pm 39.76^{\mathrm{d}}$ & $164.3 \pm 17.24^{\mathrm{e}}$ \\
\hline 100 & $100.8 \pm 4.29^{b}$ & $61.5 \pm 5.52^{\mathrm{a}}$ & $108.9 \pm 6.31^{\mathrm{c}}$ & $112.2 \pm 15.75^{\mathrm{d}}$ & $120.4 \pm 7.88^{\mathrm{e}}$ \\
\hline 125 & $73.5 \pm 12.61^{b}$ & $52.1 \pm 4.91^{\mathrm{a}}$ & $80.9 \pm 11.59^{c}$ & $85.2 \pm 6.61^{\mathrm{d}}$ & $90.9 \pm 8.97^{\mathrm{e}}$ \\
\hline 150 & $50.1 \pm 6.06^{\mathrm{a}}$ & $44.2 \pm 2.94^{\mathrm{a}}$ & $62.9 \pm 4.93^{\mathrm{b}}$ & $62.8 \pm 8.93^{b}$ & $73.8 \pm 9.77^{\mathrm{c}}$ \\
\hline \multirow{2}{*}{$\begin{array}{l}\text { Dose } \\
\left(\mathrm{mgL}^{-1}\right)\end{array}$} & \multicolumn{5}{|c|}{ Recovery time (sec) ${ }^{*}$} \\
\hline & $0 \mathrm{ppt}$ & $10 \mathrm{ppt}$ & $20 \mathrm{ppt}$ & $30 \mathrm{ppt}$ & $40 \mathrm{ppt}$ \\
\hline 50 & $185.0 \pm 26.94^{\mathrm{c}}$ & $133.2 \pm 14.81^{\mathrm{a}}$ & $163.2 \pm 26.33^{b}$ & $160.8 \pm 20.84^{b}$ & $159.1 \pm 21.48^{\mathrm{b}}$ \\
\hline 75 & $188.5 \pm 29.02^{\mathrm{d}}$ & $125.7 \pm 18.49^{\mathrm{a}}$ & $155.7 \pm 15.10^{b}$ & $145.9 \pm 16.04^{\mathrm{c}}$ & $145.8 \pm 18.59^{\mathrm{c}}$ \\
\hline 100 & $196.5 \pm 22.98^{\mathrm{c}}$ & $116.7 \pm 13.28^{\mathrm{a}}$ & $146.7 \pm 21.73^{b}$ & $145.6 \pm 20.58^{b}$ & $146.2 \pm 20.05^{\mathrm{b}}$ \\
\hline 125 & $193.8 \pm 34.00^{\mathrm{d}}$ & $123.5 \pm 20.38^{\mathrm{a}}$ & $143.5 \pm 20.97^{b}$ & $151.9 \pm 13.03^{\mathrm{bc}}$ & $152.1 \pm 12.04^{\mathrm{c}}$ \\
\hline \multirow[t]{3}{*}{150} & $175.6 \pm 33.94^{\mathrm{d}}$ & $131.3 \pm 9.20^{\mathrm{a}}$ & $157.4 \pm 12.10^{\mathrm{b}}$ & $151.3 \pm 14.33^{\mathrm{c}}$ & $157.5 \pm 13.20^{\mathrm{b}}$ \\
\hline & \multicolumn{5}{|c|}{ Two-way ANOVA (exposure time) } \\
\hline & DF & Anova SS & Mean square & $F$-value & $P$-value \\
\hline Salinity & 4 & $30,475.440$ & $7,618.860$ & 26.055 & $<0.0001$ \\
\hline Dose & 4 & $618,919.0$ & $154,729.7$ & 529.150 & $<0.0001$ \\
\hline \multirow[t]{3}{*}{ Interaction } & 16 & $12,833.400$ & 802.087 & 2.743 & $<0.0001$ \\
\hline & \multicolumn{5}{|c|}{ Two-way ANOVA (recovery time) } \\
\hline & DF & Anova SS & Mean square & $F$-value & $P$-value \\
\hline Salinity & 4 & $48,654.896$ & $12,163.724$ & 29.521 & $<0.0001$ \\
\hline Dose & 4 & $5,557.856$ & $1,389.464$ & 3.372 & $<0.0110$ \\
\hline Interaction & 16 & $9,551.864$ & 596.992 & 1.449 & $<0.1210$ \\
\hline
\end{tabular}

${ }^{*}$ Each value is mean \pm standard error of duplicate experiments. Values in the same column not sharing common superscripts are significantly different $(P<0.05)$. 
Colorado, USA) and the respiratory frequencies (gill cover movements) of the fish were measured with a counter and a digital timer. DO was measured with an oxygen electrode and a multidata logger system (Oxyguard, Denmark).

\section{Statistical analysis}

The data were analyzed with one- and two-way ANOVA with the SPSS statistical package (SPSS 9.0, SPSS Inc., USA). Differences between means were evaluated with Duncan's multiple range test and considered significantly different at $P<0.05$.

\section{RESULTS}

No fish died from stress due to anesthesia during this anesthetic experiment. Table 1 shows the anesthetic effects of clove oil at each concentration and water salinity. Anesthetic time was significantly affected by water salinity and clove oil concentrations, and decreased drastically as the concentration of clove oil increased $(P<0.05)$. However, the anesthetic effects on water salinity show a different trend. Anesthesia times increased in the other salinities excepted for 0 ppt. Furthermore, at each salinity concentration, the anesthetic time at $10 \mathrm{ppt}$ was faster than the other salinities. In addition, the pattern of recovery time was similar to that of anesthetic time $(P<0.05)$. With the exception of $0 \mathrm{ppt}$, recovery time increased gradually at all other salinities. At $10 \mathrm{ppt}$, the recovery time at each salinity concentration was faster than the other salinities. It is important to note that the recovery times of clove oil in each concentration were similar that each salinity. Fig. 1 shows the concentration of clove oil and the ratios of recovery times in relation to anesthesia time relative to the water salinity. In terms of trends, the ratio of recovery time to anesthesia time gradually increased as clove oil concentration increased at each water salinity group $(P<0.05)$. However, at each clove oil concentration, the ratio of the recovery time to anesthesia time in relations to the water salinity decreased with the exception of $75 \mathrm{ppm}(P<0.05)$.
Table 2 shows the anesthetic effects of lidocaine- $\mathrm{HCl}$ at each concentration and water salinity. At each salinity, the anesthesia time decreased drastically as the concentration of lidocaine- $\mathrm{HCl}$ increased $(P<0.05)$. The anesthesia time increased as water salinity increased between $200 \mathrm{ppm}$ and $400 \mathrm{ppm}$. At other concentrations, the pattern of lidocaine-

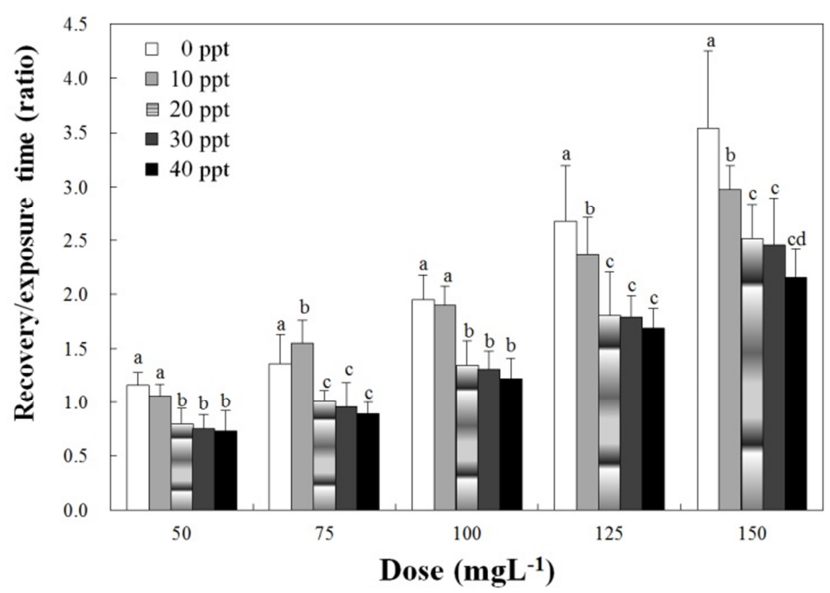

Fig. 1. Effect of clove oil dose and water salinity on the ratio of recovery time/exposure time among marine medaka, Oryzias dancena. Error bar represents the standard error of duplicate experiments. Different letters on the bars indicate statistical significance $(P<0.05)$.

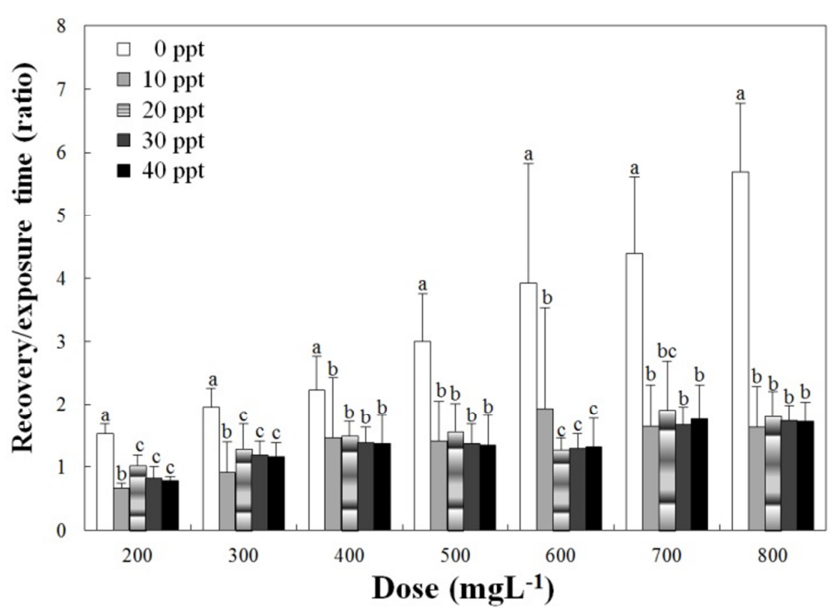

Fig. 2. Effect of lidocaine-HCl dose and water salinity on the ratio of recovery time/exposure time among marine medaka, Oryzias dancena. Error bar represents the standard error of duplicate experiments. Different letters on the bars indicate statistical significance $(P<0.05)$. 
I-S Park, HW Gil, TH Lee, YK Nam, SG Lim, DS Kim

$\mathrm{HCl}$ was similar to that of clove oil. Recovery time exhibitted a similar pattern, but the anesthesia time pattern differed. As the concentration of lidocaine- $\mathrm{HCl}$ increased, recovery time at each concentration decreased at each salinity group. At $0 \mathrm{ppt}$, the recovery time at each concentra- tion was slower than at any other salinity. However, at 10 ppt, the recovery time was faster than at any other salinity. At water salinities over $20 \mathrm{ppt}$, recovery time decreased as water salinity increased $(P<0.05)$.

Fig. 2 shows the concentrations of lidocaine- $\mathrm{HCl}$ and

Table 2. Effects of lidocaine-HCl dose and starting water salinity on anesthesia among marine medaka, Oryzias dancena

\begin{tabular}{|c|c|c|c|c|c|}
\hline \multirow{2}{*}{$\begin{array}{c}\text { Dose } \\
\left(\mathrm{mgL}^{-1}\right)\end{array}$} & \multicolumn{5}{|c|}{ Exposure time $(\mathrm{sec})^{*}$} \\
\hline & $0 \mathrm{ppt}$ & $10 \mathrm{ppt}$ & $20 \mathrm{ppt}$ & $30 \mathrm{ppt}$ & $40 \mathrm{ppt}$ \\
\hline 200 & $250.1 \pm 14.90^{\mathrm{a}}$ & $313.3 \pm 12.43^{b}$ & $323.8 \pm 38.75^{\mathrm{c}}$ & $397.4 \pm 95.78^{\mathrm{d}}$ & $396.1 \pm 63.49^{d}$ \\
\hline 300 & $182.4 \pm 21.25^{\mathrm{a}}$ & $255.8 \pm 29.20^{\mathrm{b}}$ & $255.2 \pm 33.69^{b}$ & $260.9 \pm 39.18^{b c}$ & $263.0 \pm 30.29^{c}$ \\
\hline 400 & $150.0 \pm 33.78^{\mathrm{a}}$ & $170.1 \pm 17.76^{\mathrm{b}}$ & $187.9 \pm 15.38^{\mathrm{c}}$ & $200.9 \pm 27.14^{\mathrm{d}}$ & $199.0 \pm 16.46^{\mathrm{d}}$ \\
\hline 500 & $110.4 \pm 15.46^{\mathrm{b}}$ & $105.3 \pm 32.22^{\mathrm{a}}$ & $158.9 \pm 28.97^{\mathrm{c}}$ & $167.1 \pm 23.27^{\mathrm{c}}$ & $167.9 \pm 28.31^{\mathrm{c}}$ \\
\hline 600 & $83.0 \pm 15.32^{\mathrm{a}}$ & $82.4 \pm 28.19^{\mathrm{a}}$ & $134.9 \pm 27.12^{\mathrm{b}}$ & $134.8 \pm 16.75^{\mathrm{b}}$ & $138.8 \pm 43.29^{c}$ \\
\hline 700 & $76.0 \pm 16.63^{\mathrm{b}}$ & $62.4 \pm 15.66^{\mathrm{a}}$ & $95.6 \pm 35.76^{\mathrm{c}}$ & $99.5 \pm 09.14^{\mathrm{c}}$ & $101.5 \pm 34.31^{\mathrm{d}}$ \\
\hline 800 & $57.0 \pm 8.91^{\mathrm{b}}$ & $47.6 \pm 7.21^{\mathrm{a}}$ & $74.7 \pm 12.05^{\mathrm{c}}$ & $76.6 \pm 04.86^{\mathrm{c}}$ & $78.7 \pm 17.18^{\mathrm{c}}$ \\
\hline \multirow{2}{*}{$\begin{array}{c}\text { Dose } \\
\left(\mathrm{mgL}^{-1}\right)\end{array}$} & \multicolumn{5}{|c|}{ Recovery time (sec) ${ }^{*}$} \\
\hline & $0 \mathrm{ppt}$ & $10 \mathrm{ppt}$ & $20 \mathrm{ppt}$ & $30 \mathrm{ppt}$ & $40 \mathrm{ppt}$ \\
\hline 200 & $379.0 \pm 35.45^{\mathrm{d}}$ & $208.2 \pm 20.83^{a}$ & $330.0 \pm 37.33^{\mathrm{c}}$ & $310.4 \pm 39.40^{\mathrm{b}}$ & $308.2 \pm 58.47^{\mathrm{b}}$ \\
\hline 300 & $350.0 \pm 24.81^{\mathrm{d}}$ & $234.4 \pm 131.83^{\mathrm{a}}$ & $320.5 \pm 73.06^{\mathrm{c}}$ & $305.2 \pm 34.50^{\mathrm{b}}$ & $300.5 \pm 40.80^{b}$ \\
\hline 400 & $327.2 \pm 68.13^{\mathrm{d}}$ & $260.5 \pm 169.29^{\mathrm{a}}$ & $280.5 \pm 48.56^{\mathrm{c}}$ & $272.2 \pm 38.34^{\mathrm{b}}$ & $270.4 \pm 84.46^{\mathrm{b}}$ \\
\hline 500 & $325.4 \pm 68.10^{\mathrm{d}}$ & $214.0 \pm 92.94^{\mathrm{a}}$ & $238.5 \pm 38.07^{\mathrm{c}}$ & $223.8 \pm 35.34^{b}$ & $220.1 \pm 53.95^{\mathrm{b}}$ \\
\hline 600 & $325.8 \pm 156.61^{\mathrm{b}}$ & $168.7 \pm 179.91^{\mathrm{a}}$ & $169.8 \pm 29.72^{\mathrm{a}}$ & $171.1 \pm 20.71^{\mathrm{a}}$ & $170.0 \pm 33.56^{\mathrm{a}}$ \\
\hline 700 & $323.3 \pm 67.40^{\mathrm{c}}$ & $146.9 \pm 56.28^{\mathrm{a}}$ & $167.0 \pm 43.54^{\mathrm{b}}$ & $166.8 \pm 31.70^{b}$ & $166.9 \pm 40.39^{\mathrm{b}}$ \\
\hline \multirow[t]{3}{*}{800} & $322.1 \pm 60.25^{\mathrm{c}}$ & $129.6 \pm 70.31^{\mathrm{a}}$ & $132.3 \pm 20.15^{\mathrm{b}}$ & $133.1 \pm 15.88^{b}$ & $132.5 \pm 24.74^{\mathrm{b}}$ \\
\hline & \multicolumn{5}{|c|}{ Two-way ANOVA (exposure time) } \\
\hline & $\mathrm{DF}$ & Anova SS & Mean square & $F$-value & $P$-value \\
\hline Salinity & 4 & $179,621.5$ & $4,905.379$ & 46.625 & $<0.0001$ \\
\hline Dose & 6 & $2,583,927$ & $430,654.5$ & 447.147 & $<0.0001$ \\
\hline Interaction & 24 & $92,106.646$ & $3,837.777$ & 3.985 & $<0.0001$ \\
\hline \multicolumn{6}{|c|}{ Two-way ANOVA (recovery time) } \\
\hline & $\mathrm{DF}$ & Anova SS & Mean square & $F$-value & $P$-value \\
\hline Salinity & 4 & $638,164.1$ & $159,541.0$ & 52.927 & $<0.0001$ \\
\hline Dose & 6 & $1,248,225$ & $208,037.6$ & 69.016 & $<0.0001$ \\
\hline Interaction & 24 & $191,254.8$ & $7,968.949$ & 2.644 & $<0.0001$ \\
\hline
\end{tabular}

\footnotetext{
${ }^{*}$ Each value is mean \pm standard error of duplicate experiments. Values in the same column not sharing common superscripts are significantly different $(P<0.05)$.
} 
recovery time ratios in relation to anesthesia time according to water salinity. In terms of trends, the ratio of recovery time to anesthesia time gradually increased as the lidocaine- $\mathrm{HCl}$ concentration increased at each water salinity group $(P<0.05)$. However, at each lidocaine- $\mathrm{HCl}$ concentration, the ratios of recovery time to anesthesia time according to water salinity were different from the clove oil trend. At 0 ppt, the ratio of recovery time to anesthesia time was higher than other salinities. Moreover, at all salinities excepted for $0 \mathrm{ppt}$, the ratios of $\mathrm{t}$ recovery time to anesthesia time were similar $(P<0.05)$.

At each concentration of clove oil and lidocaine- $\mathrm{HCl}$, fish were anesthetized slower at water salinities over 10 ppt. Anesthesia time at $10 \mathrm{ppt}$ was faster than at any other salinity. With the exception of $10 \mathrm{ppt}$, relationships between water salinity and anesthesia time presented a positive gradual curve, with increased water salinity (over 10 ppt) resulting in increased anesthesia time. Such a proportional relationship has not been found in previous studies. For this species, lower salinity resulted in significantly shorter anesthesia induction from clove oil and lidocaine$\mathrm{HCl}(P<0.001)$.
The results for the DO concentrations, the respiratory frequencies, and the $\mathrm{NH}_{4}{ }^{+}$and $\mathrm{CO}_{2}$ concentrations in the clove-oil-administered groups are presented in Tables 3, 4, and 5 and Fig. 3, respectively. The DO concentrations and the respiratory frequencies decreased in all the experimental groups up to 48 hours $(P<0.05$; Tables 3 and 4 , respectively), whereas the $\mathrm{NH}_{4}{ }^{+}$and $\mathrm{CO}_{2}$ concentrations in all the experimental groups increased up to 48 hours $(P<0.05$; Table 5 and Fig. 3, respectively). At 6 hours, both the DO and $\mathrm{NH}_{4}^{+}$concentrations and the respiratory frequencies had decreased with increasing clove oil concentrations (all $P<0.05$ ). At 6 hours, $\mathrm{CO}_{2}$ was $12.1 \pm 2.83$ ppm for the control group, $10.5 \pm 3.35 \mathrm{ppm}$ for the $0.2 \mathrm{ppm}$ clove oil group, $9.2 \pm 2.13 \mathrm{ppm}$ for the $0.4 \mathrm{ppm}$ clove oil group, $8.4 \pm 2.01 \mathrm{ppm}$ for the $0.6 \mathrm{ppm}$ clove oil group, $7.7 \pm 1.99 \mathrm{ppm}$ for the $0.8 \mathrm{ppm}$ clove oil group, and $7.5 \pm 1.97 \mathrm{ppm}$ for the $1 \mathrm{ppm}$ clove oil group. At 12 hours, the $\mathrm{DO}, \mathrm{NH}_{4}^{+}$, and $\mathrm{CO}_{2}$ concentrations and respiratory frequencies had decreased with increasing clove oil concentrations. The $\mathrm{CO}_{2}$ concentration at 12 hours was $15.4 \pm 2.95 \mathrm{ppm}$ for the control group, $14.7 \pm 2.59 \mathrm{ppm}$ for the $0.2 \mathrm{ppm}$ clove oil group, $14.2 \pm 2.67 \mathrm{ppm}$ for the 0.4

Table 3. Dissolved oxygen concentrations during clove-oil-induced anesthesia in the marine medaka, Oryzias dancena, in a simulated transport experiment

\begin{tabular}{ccccccc}
\hline \hline \multirow{2}{*}{$\begin{array}{c}\text { Exposure } \\
\text { time (hours) }\end{array}$} & \multicolumn{5}{c}{ Dose $\left(\mathrm{mgL}^{-1}\right)^{*}$} \\
\cline { 2 - 7 } & Control & 0.2 & 0.4 & 0.6 & 0.8 & 1.0 \\
\hline 6 & $6.51 \pm 0.83^{\mathrm{a}}$ & $6.65 \pm 0.79^{\mathrm{b}}$ & $6.77 \pm 0.64^{\mathrm{c}}$ & $6.85 \pm 0.71^{\mathrm{d}}$ & $6.98 \pm 0.72^{\mathrm{e}}$ & $7.41 \pm 0.79^{\mathrm{f}}$ \\
12 & $6.04 \pm 0.79^{\mathrm{a}}$ & $6.16 \pm 0.51^{\mathrm{b}}$ & $6.23 \pm 0.48^{\mathrm{c}}$ & $6.37 \pm 0.54^{\mathrm{d}}$ & $6.46 \pm 0.45^{\mathrm{e}}$ & $6.58 \pm 0.66^{\mathrm{f}}$ \\
18 & $5.46 \pm 0.94^{\mathrm{a}}$ & $5.55 \pm 0.88^{\mathrm{b}}$ & $5.64 \pm 0.55^{\mathrm{c}}$ & $5.77 \pm 0.57^{\mathrm{d}}$ & $5.87 \pm 0.64^{\mathrm{e}}$ & $5.99 \pm 0.89^{\mathrm{f}}$ \\
24 & $5.01 \pm 0.75^{\mathrm{a}}$ & $5.12 \pm 0.43^{\mathrm{b}}$ & $5.22 \pm 0.37^{\mathrm{c}}$ & $5.31 \pm 0.66^{\mathrm{d}}$ & $5.46 \pm 0.81^{\mathrm{e}}$ & $5.58 \pm 0.75^{\mathrm{f}}$ \\
30 & $4.67 \pm 0.92^{\mathrm{a}}$ & $4.78 \pm 0.52^{\mathrm{b}}$ & $4.88 \pm 0.49^{\mathrm{c}}$ & $4.97 \pm 0.43^{\mathrm{d}}$ & $5.11 \pm 0.66^{\mathrm{e}}$ & $5.22 \pm 0.71^{\mathrm{f}}$ \\
36 & $4.00 \pm 0.77^{\mathrm{a}}$ & $4.11 \pm 0.86^{\mathrm{b}}$ & $4.23 \pm 0.59^{\mathrm{c}}$ & $4.32 \pm 0.61^{\mathrm{d}}$ & $4.44 \pm 0.50^{\mathrm{e}}$ & $4.59 \pm 0.62^{\mathrm{f}}$ \\
42 & $3.87 \pm 0.76^{\mathrm{a}}$ & $3.99 \pm 0.44^{\mathrm{b}}$ & $4.12 \pm 0.51^{\mathrm{c}}$ & $4.25 \pm 0.65^{\mathrm{d}}$ & $4.33 \pm 0.45^{\mathrm{e}}$ & $4.47 \pm 0.56^{\mathrm{f}}$ \\
48 & $3.41 \pm 0.81^{\mathrm{a}}$ & $3.52 \pm 0.52^{\mathrm{b}}$ & $3.66 \pm 0.45^{\mathrm{c}}$ & $3.74 \pm 0.50^{\mathrm{d}}$ & $3.89 \pm 0.67^{\mathrm{e}}$ & $3.97 \pm 0.40^{\mathrm{f}}$ \\
\hline
\end{tabular}

\footnotetext{
${ }^{*}$ Each value is the mean \pm standard deviation $(n=60)$ of triplicate experiments. Values in the same column not sharing
} common superscripts are significantly different among doses $(P<0.05)$. 
I-S Park, HW Gil, TH Lee, YK Nam, SG Lim, DS Kim

Table 4. Respiratory frequencies (gill cover movements) during clove-oil-induced anesthesia in the marine medaka, Oryzias dancena, in a simulated transport experiment

\begin{tabular}{|c|c|c|c|c|c|c|}
\hline \multirow{2}{*}{$\begin{array}{c}\text { Exposure } \\
\text { time (hours) }\end{array}$} & \multicolumn{6}{|c|}{ "Dose $\left(\mathrm{mgL}^{-1}\right)^{*}$} \\
\hline & Control & 0.2 & 0.4 & 0.6 & 0.8 & 1.0 \\
\hline 6 & $128 \pm 5.77^{\mathrm{a}}$ & $125 \pm 6.91^{b}$ & $117 \pm 5.64^{\mathrm{c}}$ & $105 \pm 4.13^{\mathrm{d}}$ & $98 \pm 6.22^{\mathrm{e}}$ & $91 \pm 5.93^{f}$ \\
\hline 12 & $135 \pm 4.48^{\mathrm{a}}$ & $130 \pm 4.11^{\mathrm{b}}$ & $123 \pm 6.13^{c}$ & $117 \pm 6.44^{\mathrm{d}}$ & $106 \pm 7.41^{\mathrm{e}}$ & $98 \pm 4.66^{\mathrm{f}}$ \\
\hline 18 & $129 \pm 5.31^{\mathrm{a}}$ & $125 \pm 4.38^{\mathrm{b}}$ & $114 \pm 5.55^{\mathrm{c}}$ & $107 \pm 4.77^{\mathrm{d}}$ & $98 \pm 5.58^{\mathrm{e}}$ & $93 \pm 6.38^{f}$ \\
\hline 24 & $125 \pm 3.75^{\mathrm{a}}$ & $121 \pm 5.43^{b}$ & $112 \pm 6.72^{c}$ & $101 \pm 6.98^{\mathrm{d}}$ & $96 \pm 5.81^{\mathrm{e}}$ & $88 \pm 4.96^{\mathrm{f}}$ \\
\hline 30 & $117 \pm 6.75^{\mathrm{a}}$ & $108 \pm 6.88^{b}$ & $101 \pm 7.42^{c}$ & $97 \pm 7.39^{d}$ & $88 \pm 6.13^{\mathrm{e}}$ & $77 \pm 6.88^{f}$ \\
\hline 36 & $110 \pm 5.13^{\mathrm{a}}$ & $101 \pm 8.86^{\mathrm{b}}$ & $99 \pm 4.99^{c}$ & $92 \pm 7.06^{\mathrm{d}}$ & $84 \pm 3.65^{\mathrm{e}}$ & $75 \pm 7.13^{f}$ \\
\hline 42 & $109 \pm 4.39^{\mathrm{a}}$ & $100 \pm 6.54^{b}$ & $98 \pm 5.61^{\mathrm{c}}$ & $85 \pm 6.51^{d}$ & $81 \pm 4.09^{\mathrm{e}}$ & $72 \pm 6.88^{f}$ \\
\hline 48 & $108 \pm 5.81^{\mathrm{a}}$ & $98 \pm 4.22^{b}$ & $96 \pm 6.75^{\mathrm{c}}$ & $84 \pm 7.01^{\mathrm{d}}$ & $79 \pm 6.12^{\mathrm{e}}$ & $67 \pm 5.43^{\mathrm{f}}$ \\
\hline
\end{tabular}

* Each value is the mean \pm standard deviation $(n=60)$ of triplicate experiments. Values in the same column not sharing common superscripts are significantly different among doses $(P<0.05)$.

Table 5. Ammonium concentrations during clove-oil-induced anesthesia in the marine medaka, Oryzias dancena, in a simulated transport experiment

\begin{tabular}{|c|c|c|c|c|c|c|}
\hline \multirow{2}{*}{$\begin{array}{l}\text { Exposure } \\
\text { time (hours) }\end{array}$} & \multicolumn{6}{|c|}{ Dose $\left(\mathrm{mgL}^{-1}\right)^{*}$} \\
\hline & Control & 0.2 & 0.4 & 0.6 & 0.8 & 1.0 \\
\hline 6 & $0.21 \pm 0.03^{\mathrm{a}}$ & $0.17 \pm 0.02^{b}$ & $0.15 \pm 0.04^{\mathrm{c}}$ & $0.14 \pm 0.05^{\mathrm{d}}$ & $0.11 \pm 0.03^{\mathrm{e}}$ & $0.07 \pm 0.01^{\mathrm{f}}$ \\
\hline 12 & $0.32 \pm 0.09^{\mathrm{a}}$ & $0.27 \pm 0.05^{\mathrm{b}}$ & $0.25 \pm 0.04^{\mathrm{c}}$ & $0.23 \pm 0.03^{\mathrm{d}}$ & $0.21 \pm 0.05^{\mathrm{e}}$ & $0.20 \pm 0.04^{\mathrm{f}}$ \\
\hline 18 & $0.38 \pm 0.04^{\mathrm{a}}$ & $0.35 \pm 0.04^{b}$ & $0.33 \pm 0.06^{\mathrm{c}}$ & $0.32 \pm 0.03^{\mathrm{d}}$ & $0.30 \pm 0.04^{\mathrm{e}}$ & $0.28 \pm 0.04^{\mathrm{f}}$ \\
\hline 24 & $0.44 \pm 0.05^{\mathrm{a}}$ & $0.42 \pm 0.07^{b}$ & $0.40 \pm 0.05^{\mathrm{c}}$ & $0.37 \pm 0.03^{\mathrm{d}}$ & $0.34 \pm 0.05^{\mathrm{e}}$ & $0.31 \pm 0.08^{\mathrm{f}}$ \\
\hline 30 & $0.49 \pm 0.02^{\mathrm{a}}$ & $0.46 \pm 0.04^{b}$ & $0.44 \pm 0.05^{\mathrm{c}}$ & $0.43 \pm 0.04^{\mathrm{d}}$ & $0.41 \pm 0.06^{\mathrm{e}}$ & $0.38 \pm 0.07^{\mathrm{f}}$ \\
\hline 36 & $0.58 \pm 0.07^{\mathrm{a}}$ & $0.55 \pm 0.07^{\mathrm{b}}$ & $0.52 \pm 0.04^{\mathrm{c}}$ & $0.50 \pm 0.06^{\mathrm{d}}$ & $0.47 \pm 0.09^{\mathrm{e}}$ & $0.43 \pm 0.05^{\mathrm{f}}$ \\
\hline 42 & $0.64 \pm 0.06^{\mathrm{a}}$ & $0.61 \pm 0.05^{\mathrm{b}}$ & $0.59 \pm 0.07^{\mathrm{c}}$ & $0.56 \pm 0.03^{\mathrm{d}}$ & $0.52 \pm 0.05^{\mathrm{e}}$ & $0.50 \pm 0.07^{\mathrm{f}}$ \\
\hline 48 & $0.69 \pm 0.01^{\mathrm{a}}$ & $0.66 \pm 0.05^{\mathrm{b}}$ & $0.63 \pm 0.08^{c}$ & $0.60 \pm 0.09^{d}$ & $0.57 \pm 0.05^{\mathrm{e}}$ & $0.54 \pm 0.08^{\mathrm{f}}$ \\
\hline
\end{tabular}

\footnotetext{
${ }^{*}$ Each value is the mean \pm standard deviation $(n=60)$ of triplicate experiments. Values in the same column not sharing common superscripts are significantly different among doses $(P<0.05)$.
} 


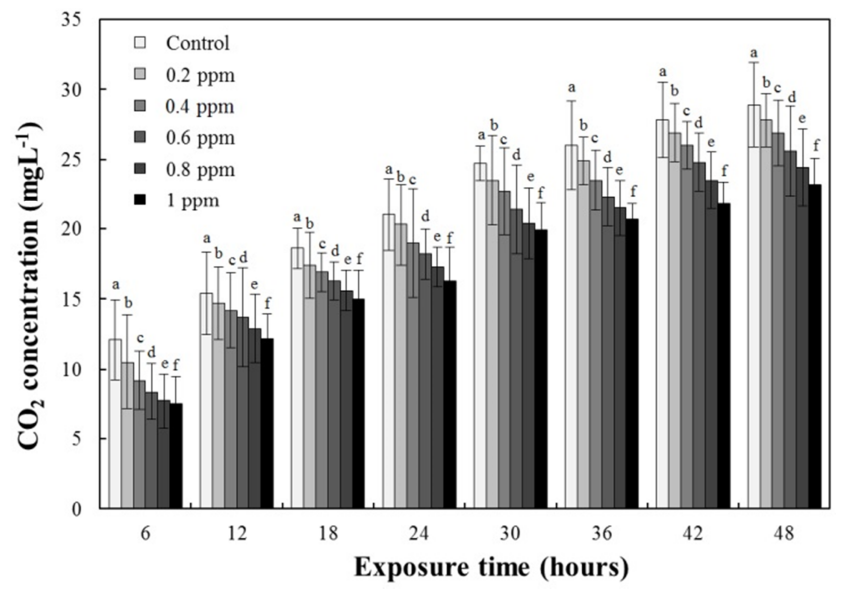

Fig. 3. Carbon dioxide $\left(\mathrm{CO}_{2}\right)$ concentrations during clove-oil-induced anesthesia in the marine medaka, Oryzias dancena, in a simulated transport experiment. Each value is the mean \pm standard deviation $(n=60)$ of triplicate experiments. Values in the same column not sharing common superscripts are significantly different among doses $(P<0.05)$.

ppm clove oil group, $13.7 \pm 3.54 \mathrm{ppm}$ for the $0.6 \mathrm{ppm}$ clove oil group, $12.9 \pm 2.44 \mathrm{ppm}$ for the $0.8 \mathrm{ppm}$ clove oil group, and $12.2 \pm 1.75 \mathrm{ppm}$ for the $1 \mathrm{ppm}$ clove oil group. At all other times (18, 24, 30, 36, 42, and 48 hours), the trends in the $\mathrm{DO}, \mathrm{NH}_{4}^{+}$, and $\mathrm{CO}_{2}$ concentrations and the respiratory frequencies for the control and clove-oil-administered groups were similar to those at 6 and 12 hours.

The results for the DO concentrations, respiratory frequencies, and $\mathrm{NH}_{4}^{+}$and $\mathrm{CO}_{2}$ concentrations in the lidocaine-HCl-administered groups are presented in Tables 6, 7, and 8 and Fig. 4, respectively. The DO concentrations and respiratory frequencies decreased up to 48 hours in all experimental groups $(P<0.05$; Tables 6 and 7, respectively), whereas the $\mathrm{NH}_{4}{ }^{+}$and $\mathrm{CO}_{2}$ concentrations increased up to 48 hours in all the experimental groups (both $P<0.05$; Table 8, Fig. 4). At 6 hours, the $\mathrm{DO}, \mathrm{NH}_{4}^{+}$, and $\mathrm{CO}_{2}$ concentrations and the respiratory frequencies had all decreased with increasing lidocaine- $\mathrm{HCl}$ concentrations $(P<0.05)$. The $\mathrm{CO}_{2}$ concentration at 6 hours was $12.1 \pm 2.83$ ppm for the control group, $11.4 \pm 3.57 \mathrm{ppm}$ for the $20 \mathrm{ppm}$ lidocaine- $\mathrm{HCl}$ group, $9.7 \pm 2.39 \mathrm{ppm}$ for the $40 \mathrm{ppm}$ lido-

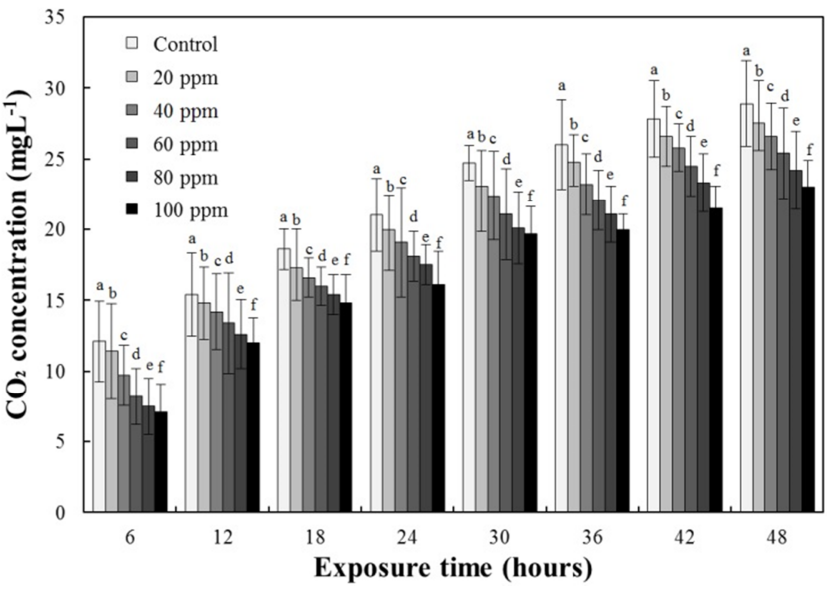

Fig. 4. Carbon dioxide $\left(\mathrm{CO}_{2}\right)$ concentrations during lidocaine-HCl-induced anesthesia in the marine medaka, Oryzias dancena, in a simulated transport experiment. Each value is the mean \pm standard deviation $(n=60)$ of triplicate experiments. Values in the same column not sharing common superscripts are significantly different among doses $(P<0.05)$.

caine- $\mathrm{HCl}$ group, $8.2 \pm 2.12 \mathrm{ppm}$ for the $60 \mathrm{ppm}$ lidocaine$\mathrm{HCl}$ group, $7.5 \pm 1.68 \mathrm{ppm}$ for the $80 \mathrm{ppm}$ lidocaine- $\mathrm{HCl}$ group, and $7.1 \pm 1.84 \mathrm{ppm}$ for the $100 \mathrm{ppm}$ lidocaine- $\mathrm{HCl}$ group. At 12 hours, the $\mathrm{DO}, \mathrm{NH}_{4}{ }^{+}$, and $\mathrm{CO}_{2}$ concentrations and the respiratory frequencies had all decreased with increasing lidocaine- $\mathrm{HCl}$ concentrations. The $\mathrm{CO}_{2}$ concentration at 12 hours was $15.4 \pm 2.95 \mathrm{ppm}$ for the control group, $14.8 \pm 2.51 \mathrm{ppm}$ for the $20 \mathrm{ppm}$ lidocaine- $\mathrm{HCl}$ group, $14.2 \pm 2.15 \mathrm{ppm}$ for the $40 \mathrm{ppm}$ lidocaine- $\mathrm{HCl}$ group, $13.4 \pm 3.64 \mathrm{ppm}$ for the $60 \mathrm{ppm}$ lidocaine- $\mathrm{HCl}$ group, $12.6 \pm 2.11 \mathrm{ppm}$ for the $80 \mathrm{ppm}$ lidocaine- $\mathrm{HCl}$ group, and $12.0 \pm 1.15 \mathrm{ppm}$ for the $100 \mathrm{ppm}$ lidocaine-HCl group. At all other times (18, 24, 30, 36, 42, and 48 hours), the trends in the $\mathrm{DO}, \mathrm{NH}_{4}{ }^{+}$, and $\mathrm{CO}_{2}$ concentrations and respiratory frequencies for the control and lidocaine-HCl-administered groups were similar to those at 6 and 12 hours.

\section{DISCUSSION}

Study results indicate that the higher the concentration of anesthetic at each salinity, the shorter the anesthesia 
I-S Park, HW Gil, TH Lee, YK Nam, SG Lim, DS Kim

Table 6. Dissolved oxygen concentrations during lidocaine-HCl-induced anesthesia in the marine medaka, Oryzias dancena, in a simulated transport experiment

\begin{tabular}{|c|c|c|c|c|c|c|}
\hline \multirow{2}{*}{$\begin{array}{l}\text { Exposure } \\
\text { time (hours) }\end{array}$} & \multicolumn{6}{|c|}{ Dose $\left(\mathrm{mgL}^{-1}\right)^{*}$} \\
\hline & Control & 20 & 40 & 60 & 80 & 100 \\
\hline 6 & $6.51 \pm 0.83^{\mathrm{a}}$ & $6.66 \pm 0.88^{b}$ & $6.76 \pm 0.74^{\mathrm{c}}$ & $6.88 \pm 0.70^{\mathrm{d}}$ & $6.97 \pm 0.52^{\mathrm{e}}$ & $7.45 \pm 0.89^{f}$ \\
\hline 12 & $6.04 \pm 0.79^{\mathrm{a}}$ & $6.14 \pm 0.55^{\mathrm{b}}$ & $6.24 \pm 0.88^{c}$ & $6.35 \pm 0.65^{\mathrm{d}}$ & $6.41 \pm 0.87^{\mathrm{e}}$ & $6.59 \pm 0.96^{\mathrm{f}}$ \\
\hline 18 & $5.46 \pm 0.94^{\mathrm{a}}$ & $5.56 \pm 0.86^{\mathrm{b}}$ & $5.67 \pm 0.95^{\mathrm{c}}$ & $5.78 \pm 0.76^{\mathrm{d}}$ & $5.85 \pm 0.91^{\mathrm{e}}$ & $5.98 \pm 1.02^{\mathrm{f}}$ \\
\hline 24 & $5.01 \pm 0.75^{\mathrm{a}}$ & $5.14 \pm 0.45^{\mathrm{b}}$ & $5.23 \pm 0.57^{\mathrm{c}}$ & $5.34 \pm 0.86^{\mathrm{d}}$ & $5.45 \pm 0.90^{\mathrm{e}}$ & $5.56 \pm 0.88^{f}$ \\
\hline 30 & $4.67 \pm 0.92^{\mathrm{a}}$ & $4.77 \pm 0.58^{\mathrm{b}}$ & $4.89 \pm 0.79^{c}$ & $4.99 \pm 0.93^{\mathrm{d}}$ & $5.13 \pm 0.98^{\mathrm{e}}$ & $5.28 \pm 0.91^{\mathrm{f}}$ \\
\hline 36 & $4.00 \pm 0.77^{\mathrm{a}}$ & $4.13 \pm 0.81^{b}$ & $4.25 \pm 0.69^{c}$ & $4.40 \pm 0.78^{\mathrm{d}}$ & $4.45 \pm 1.05^{\mathrm{e}}$ & $4.58 \pm 0.88^{\mathrm{f}}$ \\
\hline 42 & $3.87 \pm 0.76^{\mathrm{a}}$ & $3.97 \pm 0.47^{\mathrm{b}}$ & $4.15 \pm 0.81^{\mathrm{c}}$ & $4.28 \pm 0.77^{\mathrm{d}}$ & $4.37 \pm 1.01^{\mathrm{e}}$ & $4.49 \pm 0.94^{\mathrm{f}}$ \\
\hline 48 & $3.41 \pm 0.81^{\mathrm{a}}$ & $3.51 \pm 0.52^{b}$ & $3.67 \pm 0.45^{\mathrm{c}}$ & $3.78 \pm 0.56^{\mathrm{d}}$ & $3.91 \pm 0.91^{\mathrm{e}}$ & $3.99 \pm 0.80^{\mathrm{f}}$ \\
\hline
\end{tabular}

${ }^{*}$ Each value is the mean \pm standard deviation $(n=60)$ of triplicate experiments. Values in the same column not sharing common superscripts are significantly different among doses $(P<0.05)$.

Table 7. Respiratory frequencies (gill cover movements) during lidocaine-HCl-induced anesthesia in the marine medaka, Oryzias dancena, in a simulated transport experiment

\begin{tabular}{|c|c|c|c|c|c|c|}
\hline \multirow{2}{*}{$\begin{array}{c}\text { Exposure } \\
\text { time (hours) }\end{array}$} & \multicolumn{6}{|c|}{ Dose $\left(\mathrm{mgL}^{-1}\right)^{*}$} \\
\hline & Control & 20 & 40 & 60 & 80 & 100 \\
\hline 6 & $127 \pm 5.57^{\mathrm{a}}$ & $124 \pm 6.76^{\mathrm{b}}$ & $116 \pm 5.64^{\mathrm{c}}$ & $104 \pm 4.13^{\mathrm{d}}$ & $98 \pm 7.25^{\mathrm{e}}$ & $92 \pm 5.93^{\mathrm{f}}$ \\
\hline 12 & $134 \pm 4.67^{\mathrm{a}}$ & $129 \pm 4.25^{\mathrm{b}}$ & $121 \pm 6.13^{c}$ & $115 \pm 6.44^{\mathrm{d}}$ & $106 \pm 8.14^{\mathrm{e}}$ & $97 \pm 4.66^{\mathrm{f}}$ \\
\hline 18 & $127 \pm 5.77^{\mathrm{a}}$ & $123 \pm 4.86^{\mathrm{b}}$ & $112 \pm 5.55^{\mathrm{c}}$ & $106 \pm 4.77^{\mathrm{d}}$ & $98 \pm 6.76^{\mathrm{e}}$ & $91 \pm 6.38^{\mathrm{f}}$ \\
\hline 24 & $124 \pm 3.16^{\mathrm{a}}$ & $118 \pm 5.36^{\mathrm{b}}$ & $109 \pm 6.72^{c}$ & $100 \pm 6.98^{d}$ & $96 \pm 6.11^{\mathrm{e}}$ & $87 \pm 4.96^{\mathrm{f}}$ \\
\hline 30 & $116 \pm 6.19^{\mathrm{a}}$ & $107 \pm 6.64^{b}$ & $100 \pm 7.42^{c}$ & $94 \pm 7.39^{d}$ & $88 \pm 5.12^{\mathrm{e}}$ & $75 \pm 6.88^{\mathrm{f}}$ \\
\hline 36 & $109 \pm 5.76^{\mathrm{a}}$ & $100 \pm 8.27^{b}$ & $98 \pm 4.99^{c}$ & $90 \pm 7.06^{\mathrm{d}}$ & $85 \pm 6.78^{\mathrm{e}}$ & $74 \pm 7.13^{f}$ \\
\hline 42 & $105 \pm 4.09^{\mathrm{a}}$ & $97 \pm 6.86^{b}$ & $96 \pm 5.61^{c}$ & $83 \pm 6.51^{d}$ & $80 \pm 7.12^{\mathrm{e}}$ & $71 \pm 6.88^{f}$ \\
\hline 48 & $100 \pm 5.14^{\mathrm{a}}$ & $98 \pm 4.27^{\mathrm{b}}$ & $94 \pm 6.75^{\mathrm{c}}$ & $80 \pm 7.01^{\mathrm{d}}$ & $78 \pm 8.20^{\mathrm{e}}$ & $66 \pm 5.43^{f}$ \\
\hline
\end{tabular}

\footnotetext{
${ }^{*}$ Each value is the mean \pm standard deviation $(n=60)$ of triplicate experiments. Values in the same column not sharing common superscripts are significantly different among doses $(P<0.05)$.
} 
time at each salinity. The patterns of clove oil and lidocaine- $\mathrm{HCl}$ observed in the marine medaka are similar to previous studies on other bony fishes such as the sockeye salmon, Oncorhynchus nerka, (Woody et al., 2002) the rock bream, Oplegnthus fasciatus (Park et al., 2009), the greenling, Hexagrammos otakii (Park et al., 2003), and the winter flounder, Pleuronectes americanus (Park et al., 2004).. The dose response of the marine medaka to clove oil and lidocaine- $\mathrm{HCl}$ presented a negative exponential curve, with increased doses resulting in decreased time until the anesthesia stage A6.

Optimum anesthetic concentrations are usually expected to induce anesthesia within $3 \mathrm{~min}$ and recovery within 10 min (Son et al., 2001; Park et al., 2003). For this study, it was decided that the optimum anesthesia concentration should be at about $1 \mathrm{~min}$. Considering that the optimal anesthesia time is around $1 \mathrm{~min}$, concentrations of clove oil for the marine medaka were $150 \mathrm{ppm}$ at $0 \mathrm{ppt}, 20 \mathrm{ppt}$, and 30 ppt, and 100 ppm at 10 ppt. The optimal anesthesia concentrations of lidocaine- $\mathrm{HCl}$ on the marine medaka were $800 \mathrm{ppm}$ and $700 \mathrm{ppm}$ at $0 \mathrm{ppt}$ and $10 \mathrm{ppt}$, respectively. At $10 \mathrm{ppt}$, the optimum anesthetic concentration of clove oil and lidocaine- $\mathrm{HCl}$ for the marine medaka was similar to that found in a previous study on the marine medaka and water temperature (Park et al., 2011). Park et al. (2011) also reported that the optimum anesthetic concentration of both anesthetics at $26{ }^{\circ} \mathrm{C}$ was $100 \mathrm{ppm}$ and 700 ppm, respectively.

If the ratio of recovery time to anesthetic time is greater than 1 , the recovery time is longer than the anesthesia time. For the clove oil, the ratio is less than 1 at 50 ppm, 100 ppm in 20 ppt, 30 ppt and 40 ppt. Other data were recorded greater than 1 and, at each water salinity, the ratio of recovery time to anesthesia time increased as the anesthesia concentration was increased $(P<0.05)$. That is, anesthesia time was shortened as anesthesia concentration increased, but recovery time increased relatively. On the contrary, anesthesia time increased as anesthesia concentration was

Table 8. Ammonium concentrations during lidocaine-HCl-induced anesthesia in the marine medaka, Oryzias dancena, in a simulated transport experiment

\begin{tabular}{|c|c|c|c|c|c|c|}
\hline \multirow{2}{*}{$\begin{array}{c}\text { Exposure } \\
\text { time (hours) }\end{array}$} & \multicolumn{6}{|c|}{ Dose $\left(\mathrm{mgL}^{-1}\right)^{*}$} \\
\hline & Control & 20 & 40 & 60 & 80 & 100 \\
\hline 6 & $0.21 \pm 0.03^{\mathrm{a}}$ & $0.17 \pm 0.02^{b}$ & $0.15 \pm 0.04^{\mathrm{c}}$ & $0.13 \pm 0.05^{\mathrm{d}}$ & $0.11 \pm 0.03^{\mathrm{e}}$ & $0.07 \pm 0.01^{\mathrm{f}}$ \\
\hline 12 & $0.32 \pm 0.09^{\mathrm{a}}$ & $0.25 \pm 0.05^{\mathrm{b}}$ & $0.24 \pm 0.04^{\mathrm{c}}$ & $0.22 \pm 0.03^{\mathrm{d}}$ & $0.20 \pm 0.05^{\mathrm{e}}$ & $0.18 \pm 0.04^{\mathrm{f}}$ \\
\hline 18 & $0.38 \pm 0.04^{\mathrm{a}}$ & $0.34 \pm 0.04^{\mathrm{b}}$ & $0.32 \pm 0.06^{\mathrm{c}}$ & $0.30 \pm 0.03^{\mathrm{d}}$ & $0.28 \pm 0.04^{\mathrm{e}}$ & $0.26 \pm 0.04^{\mathrm{f}}$ \\
\hline 24 & $0.44 \pm 0.05^{\mathrm{a}}$ & $0.40 \pm 0.07^{\mathrm{b}}$ & $0.38 \pm 0.05^{\mathrm{c}}$ & $0.36 \pm 0.03^{\mathrm{d}}$ & $0.33 \pm 0.05^{\mathrm{e}}$ & $0.30 \pm 0.08^{f}$ \\
\hline 30 & $0.49 \pm 0.02^{\mathrm{a}}$ & $0.45 \pm 0.04^{\mathrm{b}}$ & $0.43 \pm 0.05^{\mathrm{c}}$ & $0.42 \pm 0.04^{\mathrm{d}}$ & $0.40 \pm 0.06^{\mathrm{e}}$ & $0.37 \pm 0.07^{\mathrm{f}}$ \\
\hline 36 & $0.58 \pm 0.07^{\mathrm{a}}$ & $0.54 \pm 0.07^{\mathrm{b}}$ & $0.51 \pm 0.04^{\mathrm{c}}$ & $0.50 \pm 0.06^{\mathrm{d}}$ & $0.47 \pm 0.09^{\mathrm{e}}$ & $0.44 \pm 0.05^{\mathrm{f}}$ \\
\hline 42 & $0.64 \pm 0.06^{\mathrm{a}}$ & $0.60 \pm 0.05^{\mathrm{b}}$ & $0.57 \pm 0.07^{\mathrm{c}}$ & $0.55 \pm 0.03^{\mathrm{d}}$ & $0.52 \pm 0.05^{\mathrm{e}}$ & $0.48 \pm 0.07^{\mathrm{f}}$ \\
\hline 48 & $0.69 \pm 0.01^{\mathrm{a}}$ & $0.64 \pm 0.05^{\mathrm{b}}$ & $0.62 \pm 0.08^{\mathrm{c}}$ & $0.58 \pm 0.09^{d}$ & $0.55 \pm 0.05^{\mathrm{e}}$ & $0.53 \pm 0.08^{\mathrm{f}}$ \\
\hline
\end{tabular}

\footnotetext{
${ }^{*}$ Each value is the mean \pm standard deviation $(n=60)$ of triplicate experiments. Values in the same column not sharing
} common superscripts are significantly different among doses $(P<0.05)$. 
reduced, but recovery time was shortened relatively $(P<$ 0.05). A similar result was reported for the rock bream (Park et al., 2009) in that the increment of clove oil concentration corresponds to the increment of ratio of recovery time to anesthesia time. For lidocaine- $\mathrm{HCl}$, the ratio is less than 1 at $200 \mathrm{ppm}$ in $30 \mathrm{ppt}$ and $40 \mathrm{ppt}$. Other ratios of recovery time to anesthesia time are greater than 1 . This means that recovery time is longer than the anesthesia time for lidocaine-HCl. No other specific regulation was found from this result.

For specific details of this research, anesthesia time and recovery time were fastest at $10 \mathrm{ppt}$. Anesthesia of fish is accomplished through the gills. High metabolism causes rapid breathing. If metabolism is high, the anesthesia is absorbed faster through the gills (Summerfelt \& Smith, 1990). Thus, metabolism of the marine medaka at $10 \mathrm{ppt}$ is expected to be higher than at any other salinity. Results show that anesthetic time and recovery time at $10 \mathrm{ppt}$ are faster than other salinities for further confirmation, comparative physiology research needs to be undertaken to determine these details.

The patterns of DO decline in the water of the control groups, the clove-oil-administered groups, and the lidocaine-HCl-administered groups are consistent with the trends reported in studies of Rhynchocypris steindachneri, olive flounder, Paralichthys olivaceus, and winter flounder, Pleuronectes americanus (Ko et al., 1995; Park et al., 1998; Park et al., 2009). Based on these results, we can assume that the high oxygen consumption during the early stage of transportation is attributable to the high levels of stress induced by handling or netting. The results of this study are similar to those of a transportation experiment by Ferreira et al. (1984), in which benzocaine-HCl was used as an anesthetic for the Java tilapia, Oreochromis mossambicus. In general, both studies showed a reduction in fish metabolism after the application of the anesthetic, which is an indication of declining oxygen consumption. In this study, there seemed to be a positive relationship between the concentrations of lidocaine- $\mathrm{HCl}$ and $\mathrm{DO}$, insofar as the group treated with the highest concentration of anesthetic exhibited the smallest decline in DO (Ferreira et al., 1984). A similarly designed experiment by Park et al. (1998), with $R$. steindachneri as the test organism, showed that the trends in DO and ventilation rates exhibited the same patterns for $2 \mathrm{~h}$ as were observed for $3 \mathrm{~h}$ in our study. Park et al. (1998) used lower lidocaine- $\mathrm{HCl}$ concentrations $(5,10$, and $20 \mathrm{ppm})$, but at a lower temperature $\left(18^{\circ} \mathrm{C}\right.$ compared with the $26^{\circ} \mathrm{C}$ we used in this experiment), which ultimately produced nearly identical trends. This is an important comparison, because it indicates the wide-ranging effects of lidocaine- $\mathrm{HCl}$ over a broad spectrum of temperatures.

Guo et al. (1995) performed a transportation experiment on the playfish, Xiphophorus maculatus (Günther), treated with three different anesthetics: 2-phenoxyethanol (200 ppm), quinaldine sulfate (10 ppm), and MS-222 (30 ppm). At 16 hours after the administration of the anesthetic, the $\mathrm{NH}_{4}^{+}$concentration in the water of the 2-phenoxyethanol group was only $65 \%$ that of the control group, $20 \%$ that of the quinaldine sulfate group, and relatively lower concentration compared with that of the MS-222 group. The trends in ammonium concentrations exhibited by the five experimental groups were consistent with the trends reported by Park et al. (1998, 2009) and Guo et al. (1995). Our conclusions are in accord with those of Park et al. $(1998,2009)$, insofar as the overall reduction in $\mathrm{NH}_{4}^{+}$excretion was directly related to the anesthetic-induced decline in metabolism.

Lidocaine- $\mathrm{HCl}$ induced the expected anesthetic effects for teleost fish in terms of their increased sedation, which is associated with a reduced metabolic rate and reduced oxygen consumption, together with reduced production of both $\mathrm{NH}_{4}^{+}$and $\mathrm{CO}_{2}$ (McFaland, 1959; Park et al., 1998, 2004, 2009). Currently, MS-222 remains the only fish an- 
esthetic approved by the FDA for the United States (Schnick \& Meyer, 1978). However, fish treated with MS222 are not edible until 21 days after its administration, which is the withdrawal period required for traces of the chemical to disappear from the flesh of the fish (Carmichael \& Tomasso, 1988). This clearly raises operational issues because the fish cannot be harvested for three weeks

This study shows that clove oil and lidocaine- $\mathrm{HCl}$ are effective techniques for anesthetizing the marine medaka. Moreover, the relationship between anesthetic effect and water salinity was examined. The two anesthetics used in this study meet the requirements of an ideal anesthesia with $3 \mathrm{~min}$ anesthesia times and $5 \mathrm{~min}$ recovery time. As mentioned by Park et al. (2011), the anesthetic effect is significantly affected by the water temperature and the clove oil or lidocaine- $\mathrm{HCl}$ concentration, and decreases proportionally as the clove oil or lidocaine- $\mathrm{HCl}$ concentration or water temperature increases. The results of Park et al. (2011) suggest that the anesthetic effects of clove oil are similar to those of lidocaine- $\mathrm{HCl}$. The results of our experiment suggest that clove oil and lidocaine- $\mathrm{HCl}$ both reduce the metabolic activity of the marine medaka, Oryzias dancena, thus reducing its ammonium excretion and its oxygen consumption. Both anesthetics are cost-effective, efficient, safe and non-toxic to the fish and the user (Park et al., 2003).

Park et al. (2014) reported that the operculum movement number increased under heat anesthesia and cold anesthesia by changing temperature. With anaesthetization at either $38^{\circ} \mathrm{C}$ or $8^{\circ} \mathrm{C}$, the whole-body cortisol level was highest at 0 hour and decreased gradually until 6 hours, whereas the whole-body glucose level was highest at 1 hour and decreased until 2 hours (Park et al., 2014). In conclusion, clove oil and lidocaine- $\mathrm{HCl}$ have been shown to be effective anesthetics, improving the transportation of the marine medaka. Results from this study will contribute to safe laboratory handling of the marine medaka, which are commonly required for use by many research studies and experiments. The results of our study should be useful for aquaculturists and transporters who require that minimal stress is imposed on fish during transport. In this study, we were not analyzed change of physiological response by clove oil and lidocaine- $\mathrm{HCl}$ anesthesia. So, future investigations on the marine medaka should focus on comparative analysis of physiological reactions by salinity and anesthetics.

\section{ACKNOWLEDGEMENTS}

This research was supported by a research grant (RP2012-AQ-045) from the National Fisheries Research and Development Institute, Korea. The authors would like to thank anonymous editors for their helpful suggestions that improved the quality of this paper. We declare that all experiments in this study comply with the current laws of Korea.

\section{REFERENCES}

Carmichael GJ, Tomasso JR (1988) Survey of fish transportation equipment and techniques. Progressive FishCulurist 50:155-159.

Carmichael GJ, Tomasso JR, Simco BA, Davis KB (1984) Characterization and alleviation of stress associated with hauling largemouth bass. Trans Amer Fish Soc 113:778-785.

Ferreira JT, Schoonbee HJ, Smith GL (1984) The use of benzocaine-hydrochloride as an aid in the transport of fish. Aquacult 42:169-174.

Gil HW, Ko MG, Lee TH, Park I-S, Kim DS (2016) Anesthetic effect and physiological response in olive flounder (Paralichthys olivaceus) to clove oil in a simulated transport experiment Dev Reprod 3:255-266

Goo IB, Im JH, Gil HW, Lim SG, Park I-S (2015) Com- 
parison of cell and nuclear size difference between diploid and induced triploid in marine medaka, Oryzias dancena. Dev Reprod 3:127-134.

Grizzle JM, Mauldin AC, Young D, Henderson E (1985) Survival of juvenile striped bass (Morone saxatilis) and Morone hybrid bass (Morone crysops $\times$ Morone saxatilis) increased by addition of calcium to soft water. Aquacult 46:167-171.

Guo F-C, Teo L-H, Chen T-W (1995) Effects of anaesthetics on the water parameters in simulated transport experiment of playfish, Xiphophorus maculatus (Günther). Aquacult Res 26:265-271.

Inoue K, Takei Y (2003) Asian medaka fishes offer new models for studying mechanisms of seawater adaptation. Comp Biochem Physiol Part B 136:635-645.

Kang CK, Tsai SC, Lee TH, Hwang PP (2008) Differential expression of branchial $\mathrm{Na}^{+} / \mathrm{K}^{+}$-ATPase of two medaka species (Oryzias latipes) and (Oryzias dancena), with different salinity tolerances acclimated to fresh water, brackish water and seawater. Comp Biochem Physiol Part A 151:566-575.

Kang EJ, Kim EM, Kim YJ, Lim SG, Sim DS, Kim YH, Park I-S (2005) Effect of lidocaine hydrochloride and clove oil as an anaesthetic on Korean rose bitterling, Rhodeus uyekii and oily bitterling, Acheilognathus koreensis. J Aquacult 18:272-279 (in Korean with an English abstract).

Kim DS, Nam YK, Bang I-C, Song HY (2009a) Early gonadogenesis and sex differentiation of marine medaka, Oryzias dancena (Beloniformes; Teleostei). Kor J Ichthyol 21:141-148 (in Korean with an English abstract).

Kim DS, Nam YK, Bang I-C, Song HY (2009b) Embryogenesis and early ontogenesis of a marine medaka, Oryzias dancena. Kor J Ichthyol 21:227-238 (in Korean with an English abstract).

Ko Y-S, Chang YJ, Kwon J-Y (1995) Changes of dissolved oxygen concentrations during the transportation of the olive flounder (Paralichthys olivaceus) seedlings. J Aquacult 8:251-260 (in Korean with an English abstract).

McFaland WN (1959) A study of the effects of anaesthetics on the behaviour and physiology of fishes. Publ Inst Mar Sci 6:23-55.

Nam YK, Cho YS, Lee SY, Kim DS (2010) Tolerance capacity to salinity changes in adult and larva of Oryzias dancena, a euryhaline medaka. Kor J Ichthyol 22:9-16 (in Korean with an english abstract).

Park I-S, Hur JW, Song YC, Im JH, Johnson SC (2004) Anaesthetic effect of lidocaine hydrochloride-sodium bicarbonate on the winter flounder (Pleuronectes americanus). Ocean Polar Res 26:475-480.

Park I-S, Jo JH, Lee SJ, Kim YA, Kim KE, Hur JW, Yoo JS, Song YC (2003) Anaesthetic effect of lidocaine hydrochloride-sodium bicarbonate and MS-222 on the greenling (Hexagrammos otakii). J Kor Fish Soc 36: 449-453 (in Korean with an English abstract).

Park I-S, Kim JH, Jung JB, Im JH (1998) Effect of lidocaine as an anaesthetic on Rhynchocypris oxycephalus and R. steindachneri. J Aquacult 11:59-66 (in Korean with an English abstract).

Park I-S, Kim YJ, Goo IB, Kong H-J, Kim B-S (2014) Changing temperature affects anesthetic effects and physiological stress responses in marine medaka, Oryzias dancena. J Fish Mar Sci Edu 26:270-283.

Park I-S, Park SJ, Gil HW, Nam YK, Kim DS (2011) Anesthetic effects of clove oil and lidocaine- $\mathrm{HCl}$ on marine medaka, Oryzias dancena. Lab Animal 40:45-51.

Park MO, Im S-Y, Seol D-W, Park I-S (2009) Efficacy and physiological responses of rock bream (Oplegnathus fasciatus) to anesthetization with clove oil. Aquacult 287:427-430.

Roberts TR (1998) Systematic observations on tropical Asian medakas or ricefishes of genus Oryzias, with de- 
scriptions of four new species. Ichthyol Res 45:213224.

Schnick RA, Meyer FP (1978) Registration of thirty-three fishery chemicals; status of research and estimated costs of required contract studies. Invest Fish Con 86:1-19.

Son MH, Park MW, Myeong JI, Kim DJ, Kim BH, Jo QT, Jeon IG (2001) Anaesthetic tolerance of juvenile black rockfish (Sebastes schlegeli), produced for wild stock enhancement. Ocean Polar Res 23:285-290.

Staurnes M, Sigholt T, Pedersen HP, Rustad T (1994) Physiological effects of simulated high-density transport of Atlantic cod (Gadus morhua). Aquacult 119: 381-391.
Summerfelt RC, Smith LS (1990) Anesthesia, surgery, and related techniques. In: Methods for Fish Biology, Amer Fish Soc, Bethesda, MD, USA, pp 213-272.

Tomasso JR, Davis KB, Parker NC (1980) Plasma corticosteroid and electrolyte dynamics of hybrid striped bass (white bass $\times$ striped bass) during netting and hauling stress. Proceedings World Mari Soc 11:303-310.

Woody CA, Nelson J, Ramstad K (2002) Clove oil as an anesthetic for adult sockeye salmon (Oncorhynchus nerka): field trials. Journal of Fish Biology 60:340-347.

Woolsey J, Holcomb M, Ingermann RL (2004) Effect of temperature on clove oil anesthesia in steelhead fry. North Amer J Aquacult 66:35-41. 